\title{
CLASSIFICATION OF ENTERPRISE INTEGRATION FORMS IN THE RUSSIAN INDUSTRY
}

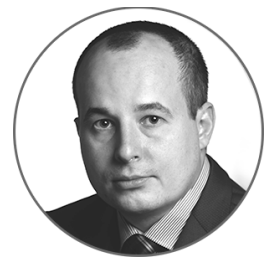

Article history:

Received 23 May 2016

Received in revised form

20 June 2016

Accepted 18 July 2016

Translated 25 May 2017

Available online 15 June 2017

JEL classification: G32, G34, L14

Keywords: integration, industry, mergers and acquisitions, cooperation

\begin{abstract}
Importance Various forms of business combinations result from implementing the integration strategy in the Russian industry. Classifications of these forms were developed by Russian scientists, however, most of them either do not cover the totality of forms or are not based on a clear criterion of classification. These downsides necessitate improvement of existing approaches to classification of forms of enterprise integration in the Russian industry.

Objectives The study aims to improve the methodological support to the management of industrial enterprise integration based on systematization of forms of integration by the essence criterion.

Methods The paper employs general scientific methods of research, like analysis, synthesis, deduction, induction, ascension from abstract to concrete. The theoretical and information basis of the research comprises articles and monographs of domestic and foreign scholars specializing in enterprise integration, and financial and nonfinancial reporting of the Russian industrial enterprises and groups.

Results I elaborated a classification of integration forms of the Russian industrial enterprises based on the formulation of the basic clear classification criteria, i.e. the availability of control exercised by the initiator of integration over other companies included in the combination. I also verified the developed classification by examples from the business practice of Russian industrial enterprises.

Conclusions and Relevance The article may be useful for analyzing integration processes in the Russian industry and developing the growth strategy of industrial enterprises.
\end{abstract}

(c) Publishing house FINANCE and CREDIT, 2016

The editor-in-charge of this article was Irina M. Komarova

Authorized translation by Irina M. Komarova

As defined in the contemporary dictionary of economics, the integration (Latin integer meaning 'whole, complete') refers to uniting of economic agents, deepening their cooperation, developing their mutual relations. Economic integration may take place at the level of national economies, and at the level of enterprises, firms, companies, corporations.

Economic integration implies an extension and deepening of productive and technological ties, joint use of resources, merge of capitals, creation of mutually favorable conditions for business operations, and lifting of reciprocal barriers ${ }^{1}$.

Most Russian scholars, such as Yu.B. Vinslav, V.E. Dement'ev, A.Yu. Melent'ev and Yu.V. Yakutin, I.G. Vladimirova, S.V. Dodonova, D.Yu. Nikologorskii, A.D. Radygin, N.B. Rudyk and E.V. Semenkova, L.P. Strakhova and A.E. Bartenev, I.A. Khrabrova [1-9],

\footnotetext{
${ }^{1}$ Raizberg B.A., Lozovskii L.Sh., Starodubtseva E.B. Sovremennyi ekonomicheskii slovar' [Contemporary dictionary of economics]. Moscow, INFRA-M Publ., 2011, 512 p.
} 
A.I. Panov², M.V. Kudina ${ }^{3}$, O.A. Romanenko ${ }^{4}$, point out the following integration strategies:

- horizontal;

- vertical;

- diagonal (diversification).

S.F. Reed, renown American expert in enterprise integration, offered this classification for the first time in 1977 [10]. Reed outlined the method for gradual preparation of a strategic business development plan, Wheel of Opportunity / Fit Chart (WOFC). The WOFC is based on choosing one of the three integration strategies.

In case of the horizontal integration, the entity grows within the industry, uniting with other entities involved in similar activities. First of all, this strategy is justifiable when the entity strives to increase its market share by absorbing competitors.

Horizontal integration can be illustrated with the merger that took place in 2011 when two major manufacturers of potassium fertilizers in Russia OAO Uralkali and OAO Silvinit - merged and created the largest potash producer in the world.

Vertical integration pushes the entity to grow across industries and sectors and consolidate with producers of resources needed to manufacture the main product (backward integration, reverse integration), or unite with entities that deal with further processing of the main product or distribute it (forward integration, direct integration). Adopting this strategy, the initiating party, first of all, intends to increase value added of the main product, improve the quality of purchased resources and distribution. Direct integration took place when Rosneft Oil Company acquired TNK-Sheremetyevo in 2013 that dealt with sale, storage of aviation fuel and fuel filling. As for the reverse integration, in 2013, Evraz Group, one of the largest Russian steel producers, acquired Timir Mining and Metallurgical Plant that produced iron ore.

\footnotetext{
${ }^{2}$ Panov A.I. [The strategy for corporate mergers in the industrial sector]. Ekonomicheskii analiz: teoriya I praktika = Economic Analysis: Theory and Practice, 2004, no. 16, pp. 10-13. (In Russ.)

${ }^{3}$ Kudina M.V. [Opportunity for corporate growth through mergers and acquisitions]. Finansy $i$ kredit = Finance and Credit, 2010, no. 4, pp. 42-52. (In Russ.)

${ }^{4}$ Romanenko O.A. [Developing the theory of integration and defining it for corporate finance governance]. Finansy $i$ kredit = Finance and Credit, 2010, no. 46, pp. 55-64. (In Russ.)
}

Diagonal integration (diversification) is a strategy for a cross-industry growth, when the entity consolidates with another entity that has no relation to its core business.

Entities often opt for this strategy when entities try to mitigate their risks after a possible recession in the sector. As the key principle, the integration initiator does not 'put all eggs in one basket'. When profits go down in the industry, where the parent company operates, profits may rise in those industries where its subsidiaries work. It will help a business survive. For example, Basic Element Group regularly acquires enterprises operating in power engineering, mining, metallurgy, machine building, aviation, etc.

Some researchers mention such integration strategies as circular integration (when the entity consolidates with another entity working with the integration initiator in the same market, but without competing with it) [11], combined integration (combination with the entity that concurrently performs activities along the technological chain and manufactures similar types of products) [12], parallel integration or generic mergers (consolidation with the producer of complementary goods) $[3,11]$. However, the said integration strategies are varieties or combinations of basic strategies.

Integration strategies engender various forms of integrated business combinations in the industrial sector. Many scholarly proceedings focus on the classification of enterprise integration forms. For example, these aspects were studied by A.G. Butrin and D.L. Yarushin [13], E.G. Guzhva and I.A. Agapov [14], Yu.V. Ignatishin [11], D.Yu. Matvienko [15], A.I. Miller [16], I.O. Sorokina ${ }^{5}$, L.B. Trofimova ${ }^{6}$ et al. However, most of enterprise integration classification systems, which were formulated by the Russian scholars, fail to embrace all business combinations [11, 13] or lack a well-defined classification criterion, without creating any logical rationale for some forms, and authors do not illustrate them with business cases [14-16].

In her research, I.G. Vladimirova provides the fullest list of enterprise integration forms (10 forms). Most of the Russian scholars refer to Vladimirova's research [2].

\footnotetext{
${ }^{5}$ Sorokina I.O. [Classification of integration combination forms]. Finansy $i$ kredit = Finance and Credit, 2009, no. 42, pp. 46-52. (In Russ.)

${ }^{6}$ Trofimova L.B. [Structuring of forms and types of business combinations in compliance with IFRS 3 Business Combinations]. Mezhdunarodnyi bukhgalterskii uchet = International Accounting, 2011, no. 9, pp. 2-6. (In Russ.)
} 
However, the above research does not set out a classification as it is, but rather enumerates the forms. I.G. Vladimirova divides all the integration forms into rigid and soft ones but does not explain how the forms should be distinguished.

In her opinion, the rigid forms of integrated structures include trusts, concerns, conglomerates, holding companies. The soft forms comprise syndicates, cartels, pools, consortia, associations, strategic alliance.

I believe if Vladimirova's list is more specified and supplemented, it may become the cornerstone for the classification of enterprise integration forms involving enterprises of the Russian industrial sector. Hence, it is necessary to determine how integrated structures should be attributed to soft or rigid types.

Considering the economic substance of integrated structures classified as rigid and soft, the integration initiator of rigid forms is obvious to have control of respective enterprises, through interests in their authorized capital. Such control is nonexistent in soft structures.

Referring to control in this article, I mean the interpretation provided in IFRS 10 Consolidated Financial Statements, 'an investor controls an investee when it is exposed, or has rights, to variable returns from its involvement with the investee and has the ability to affect those return through its power over the investee'.

Rigid structures originate from integration deals, i.e. deals for acquisition of control over the entity's operations. Mergers and acquisitions (M\&A) are qualified as such deals in international practices $[11,17,18]$.

Literature and legal documents lack an agreed-upon view of these terms and their interpretation (Tab. 1).

Thus, the terms merger and acquisition ${ }^{7}$ are economically similar. The difference between them is possibly rooted in legal technicalities. It is no coincidence that foreign specialists use the set expression 'Mergers and Acquisitions (M\&A)', which has its own specifics in Russian, being literary translated as mergers and absorptions. Whereas this term and this translation are currently used in the Russian scientific and business literature and practices, please note that the term 'Mergers and Acquisitions' is used throughout this article. Two components are not

\footnotetext{
${ }^{7}$ Translator's Note. The author hereinafter refers to the Russian equivalents of the terms 'mergers' and 'acquisitions'.
}

separated. That is why these words are used as synonyms in many foreign monographs translated into Russian and referred to in Tab. 1.

Analyzing the stances by Russian scholars, it becomes evident that their perceptions and views of the M\&A terminology are pierced through with the Russian civil laws.

As set forth in paragraph 1, Article 58 of the RF Civil Code, in case of the merger of the legal entities, the rights and duties of every one of them shall pass to the newly created legal entity. The RF Civil Code qualifies the merger as a form of the legal entity's restructuring. That is, in terms of the Russian laws, the merger is often accompanied with the termination of uniting entities, and the incorporation of a new legal entity (this procedure for joint-stock companies is set forth in Article 16 of Federal Law On Joint-Stock Companies of December 25, 1995 № 208-Ф3. As per this Federal Law, the merger of legal entities shall mean the incorporation of a new legal entity through transfer and assignment of all rights and duties of two or several entities, with their operations being discontinued). Inforeign practices, such processes are called the full merger.

The term merger is not stipulated in the Russian regulatory documents. However, paragraph 2, Article 58 of the RF Civil Code mentions the term affiliation and stipulates that in case of the legal entity's affiliation to another legal entity, the rights and duties of the former legal entity shall pass to the latter legal entity. From economic perspectives, mergers and acquisitions do not fit legal forms of corporate restructuring as mentioned above. In both cases the acquired entity completely loses its legal and business independence but the difference is that merged entities will act as a new entity or one of the merged entities will become a part of the other one. Both the restructuring forms of consolidating entities, as provided for in the RF Civil Code, are in fact compliant with the Western understanding of the process.

Adhering to opinions indicated in Tab. 1, I conclude that the absorption (acquisition) differs from a merger as the absorbed (acquired) entity definitely loses its legal personality. The integration initiator acquires the control over the target. The extent of control may be different - the acquisition of a share in the authorized capital so that the acquired entity can be regarded as a subsidiary (20 percent of the authorized capital in Russia), to 100-percent of the 
authorized capital, thus taking the full control of the target. For example, Yu.V. Ignatishin points out five forms of partial control for the Russian business absorption deals [11, pp. 27-28]:

- simple form authorizing to make decisions (up to 25 percent of authorized capital);

- blocking form authorizing to obstruct decisions (25-50 percent of authorized capital);

- equitable form stipulating the equal involvement in the decision-making process (50 percent of authorized capital);

- prevailing form providing for the prevailing involvement in the decision-making process assuming that concurrently other stakeholders have the blocking power (over 50 percent but less than 75 percent of authorized capital);

- dominant form providing for approval of shareholders' decisions (over 75 percent but less than 100 percent of authorized capital).

Thus, mergers can be defined as deals for acquiring the control over one entities or several entities and incorporating a single legal entity, while absorptions (acquisitions) shall mean deals for acquiring the control over one entity or several entities without changing the number of the entities involved in the deal after it is completed.

In addition to $M \& A$ in the context of integration deals, it is worth mentioning the situation where an individual or a group of individuals acquire controlling interests in the authorized capital of several entities.

In foreign practices, such persons are called beneficiary owners. The Russian legislation also envisages this concept. As set forth in Federal Law On Countering Legalization of Criminal Proceeds and Financing Terrorism of August 7, 2001 № 115-Ф3, beneficiary owner shall mean an individual, who is, directly or indirectly (through third parties), the ultimate holder (has/have a majority interest in more than 25 percent of capital) of the entity or controls it.

This type of integration deals is very typical of the Russian market of corporate control. Furthermore, neither merger nor acquisition in their classical meaning takes place, however, a group of entities commences coordinated activities under the joint control of shareholders who are physical persons, i.e. the economic substance of such deals is identical to the economic substance of mergers and acquisitions but just with different legal formats.

Therefore, integration deals in the Russian industrial sector include:

- mergers;

- absorptions (acquisitions);

- deals of beneficiary owners for acquiring the control over a group of companies.

In my opinion, it would not be quite correct to use the term rigid in relation to combinations of entities arising from integration deals, since, first, a business combination structure is not fixed and can change over time, including future integration deals, and, second, this term fails to provide a view of the economic substance of the integration structure.

As their common feature, such integration structures result in the incorporation of a business entity, i.e. mutual relations among consolidated entities ensuring their operation and development as a single unit. Hence, to denote a rigid structure, I suggest using the term integration combination of industrial entities as forged in Vladimirova's classification. This term stands for a combination of industrial and infrastructure entities held by the same owner and governed by the same management as a result of the integration deal.

According to Vladimirova's classification, soft integration structures allow their components to preserve their legal and business independence since such integration pursues benefits for each component. The integration initiator does not assume the control of components' operations through interests in their authorized capital.

In such integration structures, entities cooperate, rather than integrate with each other. According to the contemporary dictionary of economics, cooperation is a versatile form of joint or mutually agreed production based on the production distribution, commercial collaboration, mutual guarantees against risk, common protection of investment and commercial secrets ${ }^{8}$. If the entity becomes a part of such integration structures, it often makes deals with other parties of the integration structure, i.e. the cooperation may precede the integration.

\footnotetext{
${ }^{8}$ Raizberg B.A., Lozovskii L.Sh., Starodubtseva E.B. Sovremennyi ekonomicheskii slovar' [Contemporary dictionary of economics]. Moscow, INFRA-M Publ., 2011, 512 p.
} 
I suggest denoting soft integration structures in the industrial sector with a more appropriate term reflecting the economic substance of ties among respective components - cooperation-based integration combinations of industrial entities. This term shall mean a combination of independent industrial entities pursuing common goals of production, distribution, transfer of advanced technologies, and protection of industrial interests through cooperation.

Cooperation-based integration combinations of industrial entities are subdivided by purpose.

I present my own classification of forms of integration structures of industrial entities in Fig. 1.

Integration Combinations of Industrial Entities. This class of integration combinations of industrial entities draws upon cooperation ties. There are different interpretations of this concept in literature. It is referred to as a synonym of a joint-stock company $[9,28]$ or a legal entity with the share capital ${ }^{9}$, or an integrated business combination ${ }^{10}$.

In this article, I adhere to the latter interpretation, emphasizing that a corporate group has a legal entity holding the control over consolidated entities.

This approach correlates with the etymology of corporation coined from the Latin word corporation 'assuming a body', etc. Corporation-based business structures are set up when the legal entity takes control over the consolidated entities' operations as a result of an integration deal, thus resulting from merger or acquisition. Corporation-based business structures are subdivided by level of acquired control.

Corporation-based business structures include trusts and concerns.

Trust is a business combination where companies merge into a single production complex and lose their legal, production and commercial independence, with their operations being under the central control [2].

In industrial sectors, trusts are set up when the entity follows a vertical or horizontal integration strategy.

Vertically integrated trusts in the Russian industrial sectors are the Chelyabinsk Zinc Plant holding 100 percent share in Nova Holding AG (ore production),

\footnotetext{
${ }^{9}$ Bol'shoi kommercheskii slovar': ot A do Ya [Unabridged dictionary of commerce: From A to Z]. Moscow, Voina i mir Publ., 1996, 400 p.

${ }^{10}$ Malyi entsiklopedicheskii slovar'. V 4 t. T. 3 [Concise Encyclopedic Dictionary. Four volumes. Vol. 3]. Moscow, TERRA Publ., 1994, 536 p.
}

100 percent share in Sots-servis (social welfare) and 100 percent share in The Brock Metal Company Limited (production of alloys). Activities of the above enterprises are totally controlled by the Chelyabinsk Zinc Plant as their parent company, notwithstanding that these subsidiaries formally preserved their legal personality.

Horizontally integrated structures include OAO Fortum established as a result of restructuring of Tyumen Regional Generating Company and Chelyabinsk Generating Company that own eight regional thermal and electric power grids.

Concern is a combination (normally, industrially diversified) of independent entities mutually related through capital, financial ties, memoranda of interests, patent and license agreements, and close cooperation in production [2].

Concern is a softer form of integration than trust. Entities of a concern can belong to the parent company not entirely.

Concern usually includes subsidiaries (the parent company owns more than 50 percent of subsidiaries' authorized capital) and affiliates (the parent company owns from 20 to 50 percent of authorized capital). The parent company of the concern may be represented by the leading plant or holding company, the company that possesses a controlling interest and steers operations of the concern's entities, but has no production resources and production processes.

In the Russian industrial sector, the first model of the concern can be illustrated with KamAZ Group. KamAZ Group consists of more than 50 entities with their activities relating to the core activity of the plant and being controlled completely or in part by PAO KamAZ (manufacturer of motor trucks) through interests in respective authorized capital.

To exemplify the second model of a concern, I refer to Evraz Group (metallurgy), with Evraz plc being the parent company. As its core activity, this joint-stock company holds shares in authorized capital of over 150 companies of the group.

A concern can be established as a result of a vertical or horizontal integration strategy, however, the first option is more common for the industrial sector. For example, companies of Evraz Group are arranged throughout the metal value chain, from extraction of ore and coal to production and sale of steel and vanadium. However, there are horizontally structured concerns 
in the Russian industrial sector. For example, Russian Coal Group comprises four coal mining enterprises controlled by the head holding company.

Conglomerate is another form of concerns. According to the classifications of I.G. Vladimirova and some other researchers, conglomerate is regarded as a separate integration form. Conglomerate is an organizational form of enterprise integration concentrating a network of heterogeneous entities under common financial control, notwithstanding whether their activities be related or not [2].

Conglomerate is distinct among other types of concerns because it results from a diagonal integration strategy.

Renova Group is an example of conglomerates in the Russian industrial sector. Renova Group includes more than 100 enterprises in metallurgy, machine building, mining, chemicals, construction, transport, power engineering, telecommunications, utilities and housing, medicine, finance under the central control of Renova Holding Limited through interests in respective authorized capital.

However, rigid integration structures can be illustrated with other examples, rather than corporate business structures. In Russia integrated business structures often have no legal relationships like parent company subsidiary based on ownership principles, though they are actually controlled by beneficiary owners through their interests in authorized capital of all entities within the integrated business structure.

The Russian Federation saw a rise of most major integrated business structures in the 1990s. The economic, social and political situation of that period made such groups blur any legal links that could be used to trace and prove any relationships among group companies.

Such informal structures mainly appear to protect assets from negative effects of the unstable national economy, raiders, and optimize tax burden, etc. ${ }^{11}$

In international practices, such structures are called business combinations under common control. As its distinctive characteristic of integrated industrial business structure under control, entities have no interests in each other's authorized capital and do not control each other respectively.

\footnotetext{
${ }^{11}$ Ivanov A.E. [Preparation of combined financial statements of integrated business combinations under common control]. Finansovaya analitika: problemy i resheniya = Financial Analytics: Science and Experience, 2015, no. 13, pp. 42-55. (In Russ.)
}

Business combinations under common control, like integration combinations of industrial entities, can result from vertical, horizontal or diagonal integration strategies.

Basic Element Group is an example of business combination under common control. The business combination embraces more than 100 enterprises from various industries - construction, trade, agriculture and finance - controlled by Oleg V. Deripaska through his interests in respective authorized capital.

\section{Cooperation-Based Integration Combinations of Industrial Entities.}

Syndicate is a combination of homogeneous industrial enterprises, which is set up for distributing products through a common distribution channel that each company of the syndicate concludes an equal distribution contract with [2]. Rosoboronexport is a syndicate in the Russian industrial sector that consolidates all Russian enterprises manufacturing military or dual-purpose products for export.

Cartel is a combination of enterprises normally operating in the same industry, which enter into an agreement on various aspects of their commercial activities, i.e. prices, distribution markets, volumes of production and distribution, assortment, exchange of patents, human resource recruitment conditions. Distribution of products is the first aspect to be regulated in this situation [2].

I.G. Vladimirova mentions a pool as a separate form of integration structure. However, it seems unreasonable since a pool is a variety of cartels. What makes it different is that profit of all parties to the pool is directed to a mutual fund and then distributed among the parties on agreed-upon terms. In Russia and many other countries, cartels are prohibited by anti-trust laws.

In 2012, the Federal Antimonopoly Service detected an agreement among more than 20 manufacturers of caustic soda on the market division and pricing. The cartel was lead by OAO Edinaya torgovaya kompaniya (Unified Trade Company) and active for seven years.

Consortium is a provisional union of independent businesses, which may aim at various types of their coordinated business activities. Companies of consortia often undertake joint attempts to win contracts and perform them using their available 
resources [2]. For example, Instrumental Plants Consortium involves nine independent businesses specializing in manufacturing of industrial, construction and special tools and communicating with customers through the single contact center.

Association is a voluntary combination of legal entities or individuals for attaining any common business, scientific, cultural or other goal, other than profit-making [2]. The Russian Union of Entrepreneurs of Textile and Light Industry (Soyuzlegprom) unites over 100 legally independent enterprises to protect interests of the business community and consolidate efforts for outlining and enforcing industrial and technological policies for the Russian textile and light industry.

Strategic alliance emerges if two or more independent enterprises agree to cooperate so to reach certain commercial goals, generate synergy of united and mutually cumulative strategic resources of those enterprises [2]. I should mention the Sakhalin-2 Project uniting resources of Gazprom, Royal Dutch Shell plc., Mitsui \& Co. Ltd. and Mitsubishi Corporation to extract, process and transport oil and natural gas in the Far East of Russia.

My classification differs from the previous ones since it provides for a clear classification criterion (the integration initiator should have control over entities of a business combination) and definite division (components of a classifiable variety do not overlap).

This research overviews forms of integration structures and exemplifies them with cases of contemporary business practices of the Russian industrial enterprises, thus proving the adequacy of the proposed classification and its applicability for analyzing integration processes in the Russian industrial sector and outlining corporate strategies for industrial growth.

Table 1

Foreign and Russian approaches to the definition of terms merger and acquisition

\begin{tabular}{|c|c|c|}
\hline Author & Definition of Acquisition/Absorption & Definition of Merger \\
\hline \multicolumn{3}{|l|}{ 1. Foreign sources } \\
\hline S.M. Bragg & $\begin{array}{l}\text { The buyer acquires all or some assets of the seller or } \\
\text { its business }[17, \text { p. 15] }\end{array}$ & Combining two companies into one $[17$, p. 15] \\
\hline P.A. Gaughan & $\begin{array}{l}\text { Another term that is broadly used to refer to various } \\
\text { types of transactions is takeover. This term is vaguer; } \\
\text { sometimes it refers only to hostile transactions, and } \\
\text { other times it refers to both friendly and unfriendly } \\
\text { mergers [19, p. } 22]\end{array}$ & $\begin{array}{l}\text { Combination of two corporations in which only one } \\
\text { corporation survives and the merged corporation goes } \\
\text { out of existence. In a merger, the acquiring company } \\
\text { assumes the assets and liabilities of the merged } \\
\text { company [19, p. } 21]\end{array}$ \\
\hline $\begin{array}{l}\text { R. Brealey and S. Mayers; } \\
\text { T. Copeland, T. Koller and } \\
\text { J. Murrin; F.Ch. Evans and } \\
\text { D.M. Bishop }\end{array}$ & \multicolumn{2}{|c|}{$\begin{array}{l}\text { The terms 'mergers' and 'acquisitions' are viewed as synonyms denoting that one company acquires the other } \\
\text { company [20-22] }\end{array}$} \\
\hline $\begin{array}{l}\text { S.F. Reed, } \\
\text { A.R. Lajoux }\end{array}$ & $\begin{array}{l}\text { The process by which the stock or assets } \\
\text { of a corporation come to be owned by a buyer } \\
{[23, \text { p. } 23]}\end{array}$ & $\begin{array}{l}\text { A merger occurs when one corporation is combined } \\
\text { with and disappears into another corporation [23, p. 23] }\end{array}$ \\
\hline J.C. Van Horne & Acquisition is synonymous to a merger [24] & $\begin{array}{l}\text { Combination of two or more companies in which only } \\
\text { one firm survives as a legal entity }[24, \text { p. } 670]\end{array}$ \\
\hline \multicolumn{3}{|l|}{ 2. Russian sources } \\
\hline V.V. Botalova & $\begin{array}{l}\text { One company takes control over the other company } \\
\text { and manages it by purchasing all or some ownership } \\
\text { rights }[25, \text { p. } 85]\end{array}$ & $\begin{array}{l}\text { A financial transaction that combines several companies } \\
\text { into one without changing the shareholders and their } \\
\text { interests }[25, \text { p. } 80]\end{array}$ \\
\hline Yu.V. Ignatishin & $\begin{array}{l}\text { The process of assuming rights (in terms of laws } \\
\text { and articles of association) for a majority interest } \\
\text { in the authorized company, dominant partial control } \\
\text { over the acquired company with its legal personality } \\
\text { being preserved. The number of shareholders } \\
\text { remains unchanged during and after the process } \\
{[11, \text { p. } 6]}\end{array}$ & $\begin{array}{l}\text { A new company is created by obtaining all rights and } \\
\text { liabilities of two or several companies [11, p. 22] }\end{array}$ \\
\hline
\end{tabular}




\begin{tabular}{|c|c|c|}
\hline A.E. Molotnikov & \multicolumn{2}{|c|}{$\begin{array}{l}\text { The terms 'mergers' and 'acquisition' are considered as a set expression that denotes any method for acquiring } \\
\text { control over a company and its assets, whether it be a purchase of shares, bankruptcy, or a purchase of a building } \\
\text { owned by federal bodies in auction [18, p. } 11]\end{array}$} \\
\hline A.D. Radygin, R.M. Entov & $\begin{array}{l}\text { Acquisition of control over a joint-stock company by } \\
\text { purchasing its shares } \\
{[26, \text { p. 67] }}\end{array}$ & $\begin{array}{l}\text { Involvement of equal firms, friendly deal, agreed-upon } \\
\text { deal among major firms without purchase of minority } \\
\text { shares, share swap or a new company. In fact, without } \\
\text { considering technicalities relating to the size } \\
\text { of companies, share swap proportions, etc.), mergers } \\
\text { and acquisitions can be viewed as synonyms [27, p. 58] }\end{array}$ \\
\hline $\begin{array}{l}\text { N.B. Rudyk, } \\
\text { E.V. Semenkova }\end{array}$ & $\begin{array}{l}\text { A transaction for purchasing a controlling interest, } \\
\text { which results in transferring of ownership rights } \\
\text { to the buyer. Such deals often entail a change } \\
\text { in the acquired company's management and } \\
\text { its financial and production policies [7, p.10] }\end{array}$ & $\begin{array}{l}\text { A transaction for uniting two or more companies } \\
\text { into one when shares of merged companies are } \\
\text { converted and shareholders remain the same for } \\
\text { reaching common strategic goals [7, p. 9] }\end{array}$ \\
\hline
\end{tabular}

Source:Authoring

Figure 1

Classification of forms of integration groups with the participation of industrial enterprises

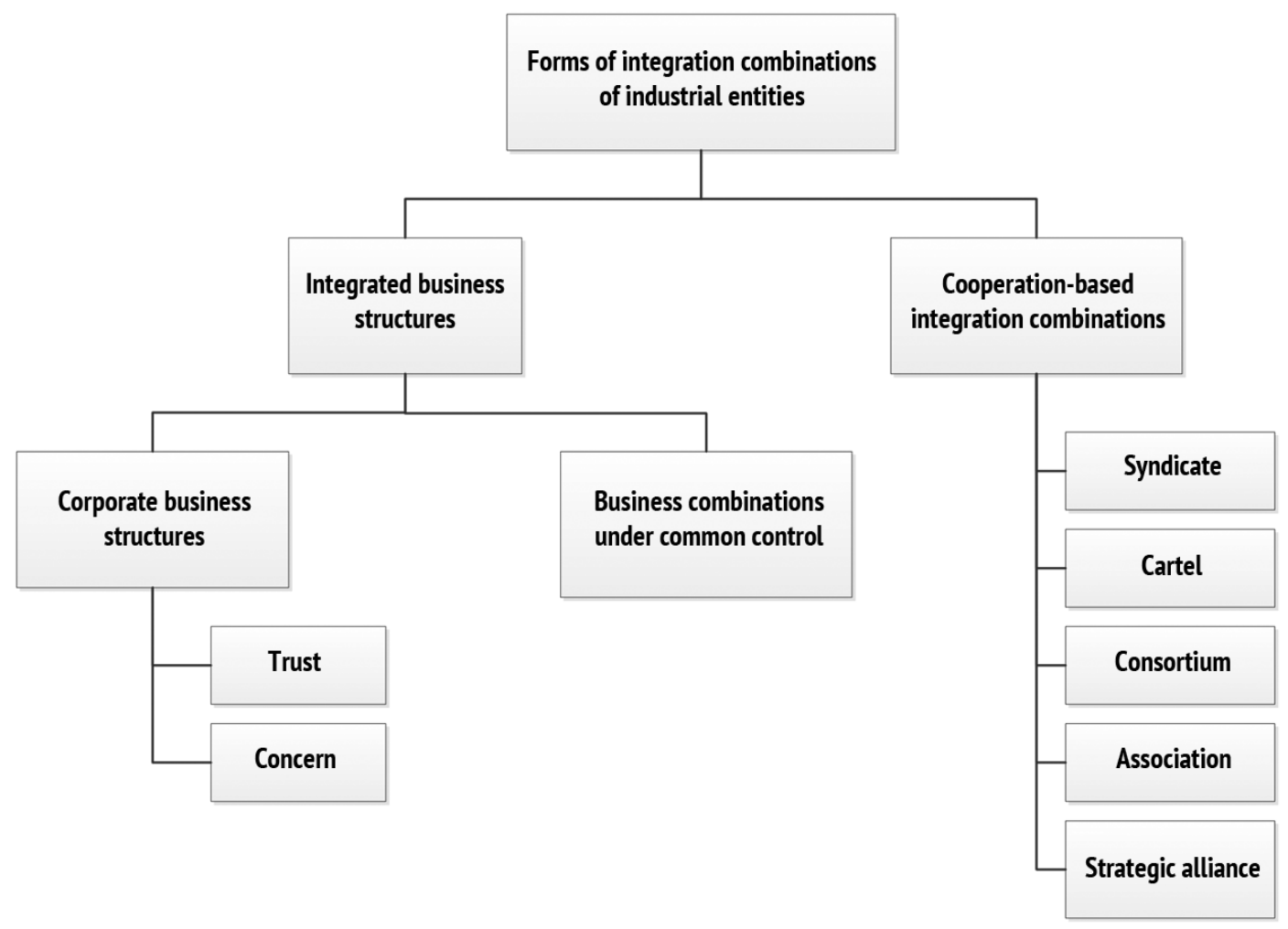

Source: Authoring

Please cite this article as: Ivanov A.E. Classification of Enterprise Integration Forms in Russian Industry. Digest Finance, 2017, vol. 22, iss. 2, pp. 144-153. Available at: https://doi.org/10.24891/df.22.2.144 


\section{Acknowledgments}

I express my gratitude and deep appreciation to Igor' A. BAEV, Doctor of Economics, Professor, Head of Economics and Finance Department of the South Ural State University, for his valuable comments on the article.

\section{References}

1. Vinslav Yu., Dement'ev V., Melent'ev A., Yakutin Yu. [Development of integrated corporate structures in Russia]. Rossiiskii ekonomicheskii zhurnal = Russian Economics Journal, 1998, no. 11-12, pp. 27-41. (In Russ.)

2. Vladimirova I.G. [Organizational forms of companies' integration]. Menedzhment $v$ Rossii $i$ za rubezhom = Management in Russia and Abroad, 1999, no. 6, pp. 113-129. (In Russ.)

3. Vladimirova I.G. [Mergers and acquisitions of companies]. Menedzhment $v$ Rossii $i$ za rubezhom = Management in Russia and Abroad, 1999, no. 1, pp. 27-48. (In Russ.)

4. Dodonova S.V. [Integration associations of economic entities]. Vestnik Finansovoi akademii = Bulletin of Financial Academy, 2003, no. 1, pp. 42-51. (In Russ.)

5. Nikologorskii D.Yu. [Large integrated structures in the industry]. $E K O=E C O, 1997$, no. 11, pp. 70-82. (In Russ.)

6. Radygin A.D. [Mergers and acquisitions in the corporate sector: Major approaches, specifics of Russia and regulation tasks]. Voprosy Ekonomiki, 2002, no. 12, pp. 85-110. (In Russ.)

7. Rudyk N.B., Semenkova E.V. Rynok korporativnogo kontrolya: sliyaniya, zhestkie pogloshcheniya i vykupy dolgovym finansirovaniem [The corporate control market: Mergers, compulsory acquisitions and buyout by leveraged finance]. Moscow, Finansy i Statistika Publ., 2000, 455 p.

8. Strakhova L.P., Bartenev A.E. [Corporate entities in modern economy]. Menedzhment $v$ Rossii $i$ za rubezhom $=$ Management in Russia and Abroad, 2000, no. 6, pp. 22-46. (In Russ.)

9. Khrabrova I.A. Korporativnoe upravlenie: voprosy integratsii [Corporate management: Integration issues]. Moscow, Al'pina Publ., 2000, 198 p.

10. Reed S.F. Corporate Growth by Strategic Planning (Part 1): Developing a Strategy. Mergers \& Acquisitions, 1977 , vol. 12, pp. 4-27.

11. Ignatishin Yu.V. Sliyaniya i pogloshcheniya: strategiya, taktika, finansy [Mergers and acquisitions: Strategy, tactics, finance]. St. Petersburg, Piter Publ., 2005, 208 p.

12. Bazhanov P.R. [Creating vertically integrated companies in the oil industry as a factor of their competitiveness]. Rossiiskoe predprinimatel'stvo = Russian Journal of Entrepreneurship, 2008, no. 4-2, pp. 52-56. (In Russ.)

13. Butrin A.G., Yarushin D.L. [Evaluation and management of integration processes in the industry]. Sovremennye problemy nauki i obrazovaniya = Modern Problems of Science and Education, 2013, no. 6. (In Russ.) Available at: http://www.science-education.ru/ru/article/view?id=11836/

14. Guzhva E.G., Agapov I.A. [Forms of integration of enterprise structures: A theoretical aspect]. Ekonomicheskoe vozrozhdenie Rossii = Economic Revival of Russia, 2011, no. 3, pp. 281-285. (In Russ.)

15. Matvienko D.Yu. [Forms of integration of companies]. Sovremennaya konkurentsiya = Journal of Modern Competition, 2012, no. 6, pp. 9-16. (In Russ.)

16. Miller A.I. [Integrated companies in the domestic industry: A historical aspect]. Rossiiskoe predprinimatel'stvo = Russian Journal of Entrepreneurship, 2012, no. 1, pp. 64-70. (In Russ.)

17. Bragg S. Sliyaniya i pogloshcheniya: prakticheskoe rukovodstvo [Mergers and Acquisitions: A Condensed Practitioner's Guide]. Moscow, Maroseika Publ., 2011, 224 p.

18. Molotnikov A.E. Sliyaniya i pogloshcheniya. Rossiiskii opyt [Mergers and acquisitions. The Russian experience]. Moscow, Vershina Publ., 2006, 344 p. 
19. Gaughan P.A. Sliyaniya, pogloshcheniya i restrukturizatsiya kompanii [Mergers, Acquisitions and Corporate Restructurings]. Moscow, Al'pina Pablisherz Publ., 2010, 741 p.

20. Brealey R., Myers S. Printsipy korporativnykh finansov [Principles of Corporate Finance]. Moscow, Olimp-Biznes Publ., 2008, 1008 p.

21. Copeland T., Koller T., Murrin J. Stoimost' kompanii: otsenka i upravlenie [Valuation: Measuring \& Managing the Value of Companies]. Moscow, Olimp-Biznes Publ., 2005, 576 p.

22. Evans F.C., Bishop D.M. Otsenka kompanii pri sliyaniyakh i pogloshcheniyakh: Sozdanie stoimosti v chastnykh kompaniyakh [Valuation for M\&A: Building Value in Private Companies]. Moscow, Al'pina Biznes Buks Publ., 2004, 332 p.

23. Reed S.F., Lajoux A.R. Iskusstvo sliyanii i pogloshchenii [The Art of M\&A: A Merger Acquisition Buyout Guide]. Moscow, Al'pina Biznes Buks Publ., 2004, 958 p.

24. Van Horne J.C. Osnovy upravleniya finansami [Fundamentals of Financial Management]. Moscow, Finansy i Statistika Publ., 2003, 800 p.

25. Botalova V.V. [Theoretical foundations of mergers and acquisitions in Russia and abroad]. Rossiiskoe predprinimatel'stvo = Russian Journal of Entrepreneurship, 2013, no. 10, pp. 76-87. (In Russ.)

26. Radygin A., Entov R. [Market of mergers and acquisitions: New theoretical approaches]. Ekonomicheskaya politika = Economic Policy, 2010, no. 5, pp. 67-91. (In Russ.)

27. Radygin A., Entov R. Problemy sliyanii i pogloshchenii v korporativnom sektore [Problems of mergers and acquisitions in the corporate sector]. Moscow, IET Publ., 2002, 153 p.

28. Dracheva E.L., Libman A.M. [Problems of definition and classification of integrated corporate structures]. Menedzhment $v$ Rossii i za rubezhom = Management in Russia and Abroad, 2001, no. 4, pp. 37-53. (In Russ.)

29. Son'kin N.B. Korporatsii: teoreticheskie i prikladnye problemy [Corporations: Theoretical and applied problems]. Moscow, Moskovskaya vysshaya yazykovaya shkola Publ., 1999, 394 p.

\section{Conflict-of-interest notification}

I, the author of this article, bindingly and explicitly declare of the partial and total lack of actual or potential conflict of interest with any other third party whatsoever, which may arise as a result of the publication of this article. This statement relates to the study, data collection and interpretation, writing and preparation of the article, and the decision to submit the manuscript for publication. 